\title{
$\mathrm{SiC}$ 플레이트를 이용한 석면 함유 폐기물의 무해화 연구
}

\author{
홍명환* · 최혁목** · 주소영* · 이찬기* . 윤진호* \\ *고등기술연구원 융합소재연구센터, **한국종합플랜트
}

\section{Study on the Detoxification of Asbestos-Containing Wastes (ACW) Using SiC Plate}

\author{
Myung Hwan Hong*, Hyeok Mok Choi**, So Young Joo*, Chan Gi Lee* and ${ }^{\S}$ Jin-Ho Yoon* \\ *Materials Science and Chemical Engineering Center, Institute for Advanced Engineering, Yongin 17180, Korea \\ **Korea Comprehensive Plant, Seoul 46201, Korea
}

\begin{abstract}
요 약
최근 인체 유해성이 높은 석면 함유 제품의 다량 폐기로 인해 석면 함유 폐기물(asbestos-containing waste: $\mathrm{ACW}$ )이 계속해서 발생하 고 있으며, 매립지 부족 등의 이유로 석면 무해화 및 재활용 기술 개발이 요구되고 있다. 마이크로웨이브를 이용한 열처리는 석면 함유 폐 기물 무해화에 가장 효율적인 방법이나 석면이 상온에서 마이크로웨이브를 흡수하지 않는 한계점을 가지고 있다. 본 연구에서는 상온에 서 마이크로웨이브를 흡수하여 발열하는 무기 발열체인 $\mathrm{SiC}$ 플레이트 사이에 석면 함유 폐기물를 위치시킨 상태에서 마이크로웨이브 열 처리를 진행하는 방법으로 석면 함유 폐기물를 무해화 하였다. 효율적인 열처리를 위하여 석면 함유 폐기물를 파쇄 및 분쇄 공정을 통해 분말화하여 무해화 열처리 실험을 진행 하였으며, 열처리 조건에 따른 무해화 특성을 파악하기 위하여 마이크로웨이브 열처리 온도와 시 간 변수를 조절하였다. 열처리 후 석면 함유 폐기물는 XRD와 SEM을 이용한 결정구조 및 미세구조 분석을 통하여 무해화 특성을 분석 하 였다. $\mathrm{SiC}$ 플레이트를 적용한 마이크로웨이브 열처리 방법은 단시간 내에 목표 온도까지 가열이 가능하며 최종적으로 $1,200^{\circ} \mathrm{C}$ 에서는 60 분 이상, $1,300^{\circ} \mathrm{C}$ 에서는 10 분 이상의 마이크로웨이브 열처리를 진행하였을 때 결정구조와 미세구조상에서 석면이 완전히 제거되는 것 을 확인하였다.
\end{abstract}

주제어 : 석면 함유 폐기물, 마이크로웨이브, $\mathrm{SiC}$, 무해화, 열처리

\begin{abstract}
Even asbestos-containing waste ( $\mathrm{ACW}$ ) are highly harmful to humans, it continues being produced due to the massive disposal of asbestos-containing products. A development of asbestos detoxification and recycling technologies is required. Heat treatment using microwave is the most efficient method for ACW detoxification. However, microwave heat treatment method has the limitation that asbestos does not absorb microwave at room temperature. That is why, in this study, ACW was detoxified by microwave heat treatment adding the $\mathrm{ACW}$ between $\mathrm{SiC}$ plates, which are inorganic heating elements that absorb microwaves at room temperature. In order to improove the heat transfer, ACW was crushed and pulverized and then heated using microwave. Microwave heat treatment temperature and time variables were adjusted to investigate the detoxification properties according to heat treatment conditions. After heat treatment, treated ACW was analyzed for detoxification properties through crystal structure and microstructure analysis using X-ray diffraction (XRD) and scanning electron microscopy (SEM).
\end{abstract}

\footnotetext{
- Received : November 27, 2019 · Revised : January 29, $2020 \cdot$ Accepted : February 5, 2020

$\S$ Corresponding Author : Jin-Ho Yoon (E-mail : yjh6373@iae.re.kr)

Materials Science and Chemical Engineering Center, Institute for Advanced Engineering, 175-28, Goan-ro 51beon-gil, Baegammyeon, Cheoin-gu, Yongin-si, Gyeonggi-do 17180, Korea

(c) The Korean Institute of Resources Recycling. All rights reserved. This is an open-access article distributed under the terms of the Creative Commons Attribution Non-Commercial License (http://creativecommons.org/licenses/by-nc/3.0/), which permits unrestricted non-commercial use, distribution and reproduction in any medium, provided the original work is properly cited.
} 
Microwave heat treatment method using SiC plate can be heated up to the target temperature within a short time. Finally, complete asbestos detoxification was confirmed from the crystal structure and the microstructure when the microwave heat treatment was performed at $1,200^{\circ} \mathrm{C}$ for at over 60 minutes and at $1,300^{\circ} \mathrm{C}$ for at over 10 minutes.

Key words : asbestos-containing wastes, microwave, SiC, detoxification, heat treatment

\section{1. 서 론}

화성암의 일종인 석면(asbestos)은 천연 섬유 모양의 규산 화합물로 사문석계와 각섬석계 두 그룹으로 나뉜 다. 사문석계에는 chrysotile이 있으며, 각섬석계 석면으로 는 crocidolite, amosite, anthophyllite asbestos, actinolite asbestos, tremolite asbestos이가 있다 ${ }^{1,2)}$. 석면 섬유는 길 이 $5 \mu \mathrm{m}$ 이상의 길이 대 폭의 비가 $3: 1$ 이상인 물질로 단열 성, 내열성, 절연성 등의 우수한 물성과 가격이 저렴하여 백 석면으로 불리는 Chrysotile, 청석면으로 불리는 crocidolite 및 갈석면으로 불리는 amosite가 산업적인 용도로 주로 사용되었다,4). 이러한 우수한 특성으로 인하여 20세기 이 후 석면은 건설, 자동차 제조 및 가정용품 등에 이르기까 지 다양한 분야에서 3,000 여 종류에 달하는 공업 제품에 사용되었다 ${ }^{5}$. 전 세계적으로 거의 모든 경제 분야에 석면 이 사용되어 왔으며 오랫동안 석면을 대체할 만한 물질은 없는 것으로 여겨졌다. 또한 과거에 석면은 광물성 규산 염이기 때문에 건강에 큰 문제가 없는 것으로 판단하여 석 면 분진으로 인한 인체 유해성에 대해서는 일반 분진 경우 와 차이를 두어 취급되지 않았다. 이렇듯 석면이 현재와 같이 유해물질로 취급되지 않았기 때문에 사용량은 증가 하였으며 세계 생산량이 1966년 280만 톤에서 1975년 520 만 톤으로 증가하였다.

그러나 1970년대 후반부터 석면 분진에 대한 인체 위 해성이 알려졌으며, 석면 분진 노출은 20 년에서 40 년의 잠복기를 거쳐 석면폐, 악성중피종, 폐암 등의 치명적인 질병 유발의 주요 원인으로 확인되었다 ${ }^{6-8)}$. 1987년 세계 보건기구 산하 국제암연구소에서 석면을 1 급 발암물질로 지정하며 석면의 유해성이 알려지면서 석면대체물질이 개발되어 사용되고 있어 현재는 감소하는 추세이다. 그 동안 사용된 석면 함유 폐기물(asbestos-containing waste: $\mathrm{ACW}$ )은 매립지에 매립하는 것도 가능하나 매립지의 부 족, 자원의 재활용 등의 이유로 석면을 무해화 하는 기술 개발에 대한 필요성이 대두되었다.
석면을 무해화하기 위하여 표면 고착화, 열 및 열화학 적 방법, 화학적방법 등 다양한 방법이 연구되었다 ${ }^{9-11)}$. 캡 슐화 방법은 석면을 해체하지 않고 불침투성 층을 형성하 여 석면이 대기 중으로 유출되는 것을 방지하는 방법으로 비교적 적은 비용으로 처리가 가능하다. 하지만 석면 형 태 및 손상 정도에 따른 적용에 한계가 존재하며 시간이 지남에 따라 재료가 손상될 경우 석면 방출의 가능성이 있 어 완전한 석면 무해화는 아니다. 폐석면의 무해화에 있 어 가장 효율적인 방법은 고온 열처리에 의한 석면 섬유를 무해한 구조로 변환시키는 방법이다 ${ }^{1,12)}$. 석면 함유 폐기 물의 열처리 방법은 $1,200^{\circ} \mathrm{C}$ 이상의 고온으로 가열하여 석면의 구조를 변환시키는 것으로 화학 물질을 첨가하여 $1,200^{\circ} \mathrm{C}$ 이하의 온도에서도 무해화가 가능하다 ${ }^{13,14}$. 그러 나 석면과 석면 함유 폐기물의 주성분인 시멘트의 낮은 열 전도율로 인한 에너지 소비가 높아짐에 따라 다량으로 처 리하는 것이 어려우며 화학물질 추가 시 처리비용이 높아 진다 ${ }^{15)}$. 마이크로웨이브를 이용한 열처리는 빠르고 균일 한 온도 상승 특성으로 인하여 폐석면을 열처리하기 위한 기존의 오븐 또는 열 플라즈마를 대체할 수 있는 기술로 고려되고 있다 ${ }^{16)}$. 하지만 $\mathrm{SiO}_{2}, \mathrm{CaCO}_{3}, \mathrm{Al}_{2} \mathrm{O}_{3}$ 와 같은 시 멘트의 주성분은 상온에서 마이크로웨이브를 투과하여 마이크로웨이브 에너지를 거의 흡수하지 않으며 마이크 로웨이브 흡수를 위해서는 일정 온도까지 가열 되어야 한 다 ${ }^{17,18)}$. 본 연구에서는 상온에서 마이크로웨이브를 흡수 하여 발열이 가능한 무기소재 플레이트를 적용한 열처리 방법을 이용하였으며, 기존 마이크로웨이브 열처리에 대 한 한계점 해결 및 공정 단순화를 하고자 하였다. 석면 무 해화 효율을 높이기 위하여 파쇄 및 분쇄 공정으로 분말화 된 석면 함유 폐기물을 무기 발열체인 무기소재 플레이트 사이에 위치시켜 무해화 실험을 진행하였다. 무기소재 플 레이트 사이에 위치한 석면 함유 폐기물 분말에 마이크로 웨이브를 조사 시, 무기 발열체에서 발열하는 열을 이용 한 열처리로 석면을 무해화하였다. 원료로는 석면 철거 현장에서 수급 된 실제 석면 함유 폐기물인 폐 슬레이트를 
사용하였다. 석면 함유 폐기물 분말과 $\mathrm{SiC}$ 무기소재 플레 이트를 사용하여 열처리 온도 및 시간의 변수에 따른 석면 의 무해화 특성에 관한 실험을 진행하였다. 마이크로웨이 브 열처리 전, 후 석면의 무해화 특성을 확인하기 위하여 $\mathrm{XRD}$ 를 이용한 결정구조 분석 및 $\mathrm{SEM}$ 을 이용한 미세구 조 분석을 진행하였다.

\section{2. 실험방법}

석면 무해화 연구에 사용된 석면 함유 폐기물은 폐 슬 레이트를 이용하였으며, 폐 슬레이트는 해체 작업 시 석 면의 비산을 방지하기 위하여 습윤 작업으로 인하여 습기 를 가지고 있기 때문에 $80^{\circ} \mathrm{C}$ 오븐에서 24시간 건조 후 미 분화 공정을 진행하였다. 건조된 폐 슬레이트는 임팩트 밀(impact mill)을 이용하여 $5 \mathrm{~mm}$ 이하로 1차 파쇄 진행 하였으며, 핀 밀(pin mill)을 이용하여 최종적으로 $1 \mathrm{~mm}$ 이하의 미분으로 제조하였다.

폐 슬레이트의 무해화는 마이크로웨이브를 조사하고 이를 흡수하여 발열되는 열을 이용한 열처리 방법으로 실 험을 진행하였으며 Fig. 1에 실험에 사용된 마이크로웨이 브 열처리 장치 및 실험 개략도를 나타내었다. 마이크로 웨이브 열처리 장치는 내부 챔버의 크기가 $800 \times 800 \times$
$680 \mathrm{~mm}$ 이며 챔버 천장의 각 면에 하나씩 총 4 개의 $1 \mathrm{~kW}$ 급 마이크로웨이브 발생장치와 적외선 온도 센서로 구성 되었다.

미분화된 폐 슬레이트는 두 개의 $\mathrm{SiC}$ 플레이트 $(80 \times$ $80 \times 15 \mathrm{~mm}$ ) 사이에 $70 \mathrm{~g}$ 을 담아서 $95 \times 95 \times 45 \mathrm{~mm}$ 의 알루미나 도가니에 위치시켰다. 무해화 열처리 시 알루미 나 도가니 외부로 방출되는 열에 의한 승온 속도 및 열처 리 효율 감소를 방지하기 위하여 도가니의 측면과 밑면은 $50 \mathrm{~mm}$ 두께의 내열보드를 이용하여 단열 하였다. 도가니 의 윗면은 도가니 내부 온도 측정을 위하여 지름 $20 \mathrm{~mm}$ 구멍이 딿려있는 $40 \mathrm{~mm}$ 두께의 멀라이트 내화 벽돌을 이 용하여 단열 하였다. 열처리 조건에 따른 폐 슬레이트의 무해화 특성 변화를 관찰하고자 열처리 온도 및 시간을 달 리하여 무해화 실험을 진행하였다. 열처리 후의 폐 슬레 이트 분말은 XRD(XRD-6100, Shimadzu)와 SEM(Mira 3, Tescan)을 이용하여 결정상 및 미세구조의 변화를 확인하 였다.

\section{3. 결과 및 고찰}

폐 슬레이트는 Fig. 2와 같이 백석면인 chrysotile $\left(\mathrm{Mg}_{3}\right.$ $\left.\left(\mathrm{Si}_{2} \mathrm{O}_{5}\right)(\mathrm{OH})_{4}\right)$ 과 시멘트의 주성분인 탄산칼슘 $\left(\mathrm{CaCO}_{3}\right)$ 이

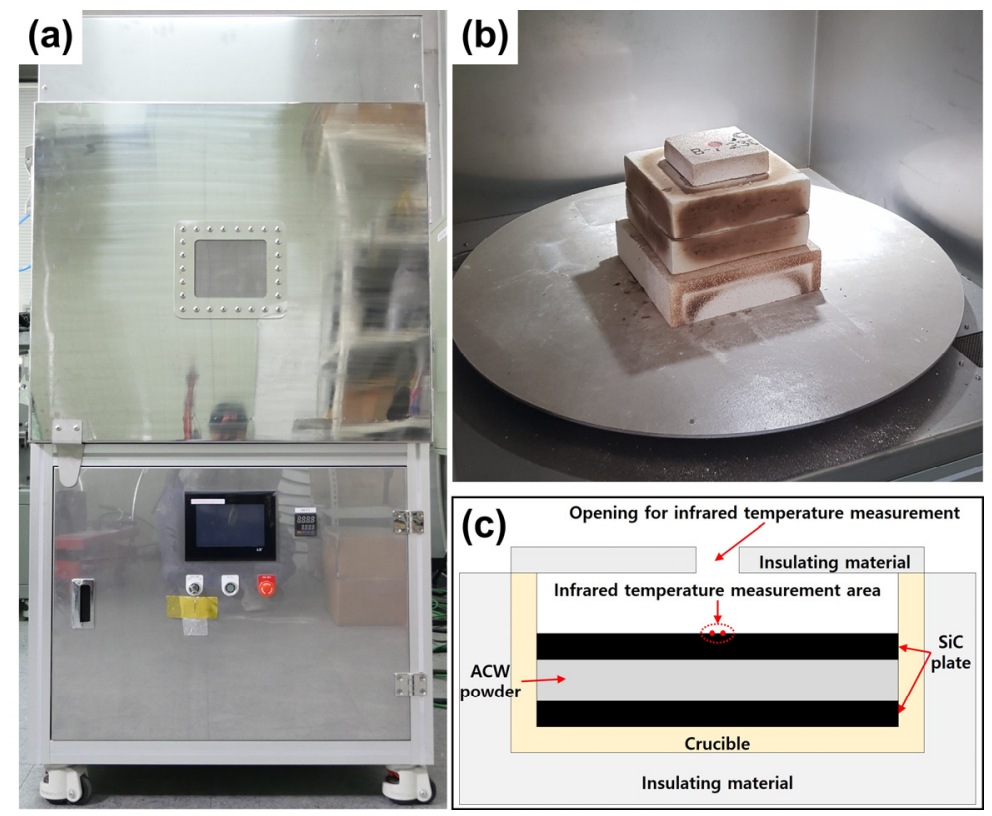

Fig. 1. (a) Microwave heat treatment device, (b) internal chamber, and (c) experimental schematic. 
$12^{\circ}$ 와 $29.5^{\circ}$ 에서 주 피크를 나타내고 있다. 탄산칼슘의 주 피크 강도가 chrysotile 보다 높은 것으로 보아 폐 슬레이 트에는 시멘트 성분이 석면 보다 많을 것으로 예상된다. 미분화된 폐 슬레이트의 미세구조 SEM으로 관찰한 결과 를 Fig. 3에 나타내었다. 시멘트와 석면이 균일하게 분포 되어 있는 것이 확인되었으며(Fig. 3(a)), 석면 조직은 미 분화 공정 후에도 섬유상이 파괴되지 않고 유지되고 있는 것이 관찰되었다(Fig. 3(b),(c)). 석면의 직경은 $1.2 \mu \mathrm{m}$ 이 하인 것으로 측정되었다.

$\mathrm{SiC}$ 플레이트를 적용한 마이크로웨이브 석면 무해화 열처리 시, 상온인 $25^{\circ} \mathrm{C}$ 에서 $1,200^{\circ} \mathrm{C}$ 까지 시간에 따른 온 도 변화를 Fig. 4 에 나타내었다. 석면 함유 폐기물은 $400^{\circ} \mathrm{C}$ 까지 낮은 마이크로웨이브 흡수율로 인하여 온도상승이 원활하지 못하여 열처리 효율 증가를 위해서는 추가적인 열원이 필요하다 ${ }^{15,19)}$. 하지만 $\mathrm{SiC}$ 플레이트를 적용한 본

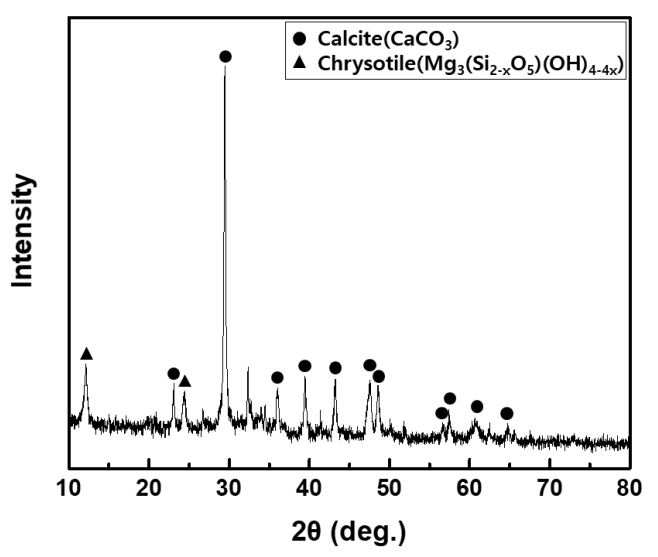

Fig. 2. XRD spectra of wasted asbestos slate.
방법의 경우, Fig. 4에서 볼 수 있듯이 $\mathrm{SiC}$ 플레이트가 상 온에서도 마이크로웨이브 흡수가 가능하여 $400^{\circ} \mathrm{C}$ 이하에 서도 빠른 온도상승을 확인 할 수 있다.

$900^{\circ} \mathrm{C}, 1,100^{\circ} \mathrm{C}, 1,300^{\circ} \mathrm{C}$ 에서 30 분 동안 마이크로웨 이브 장치를 이용하여 열처리 실험을 진행하였으며 실험 결과에 결정상을 Fig. 5 에 나타내었다. $900^{\circ} \mathrm{C}$ 와 $1,100^{\circ} \mathrm{C}$ 에서 열처리한 폐 슬레이트에서는 chrysotile 결정상이 남 아있는 것이 확인되었으며 $1,300^{\circ} \mathrm{C}$ 로 열처리한 샘플에서 는 chrysotile 결정상이 나타나지 않는 것으로 확인되었 다. 폐 슬레이트의 함유된 탄산칼슘과 chrysotile이 열처리 후 akermanite $\left(\mathrm{Ca}_{2} \mathrm{Mg}\left(\mathrm{Si}_{2} \mathrm{O}_{7}\right)\right)$, merwinite $\left(\mathrm{Ca}_{3} \mathrm{Mg}\left(\mathrm{SiO}_{4}\right)_{2}\right)$, larnite $\left(\mathrm{Ca}_{2} \mathrm{SiO}_{4}\right)$ 결정상이 생성되는 것을 확인되었다. 이 는 탄산칼슘과 chrysotile이 열에 의해서 해리된 뒤 화학 적 반응에 의해 생성된 것으로 chrysotile은 $700-800^{\circ} \mathrm{C}$ 에 서 다음과 같이 forsterite $\left(\mathrm{Mg}_{2} \mathrm{SiO}_{4}\right)$ 와 enstatite $\left(\mathrm{MgSiO}_{3}\right)$ 로

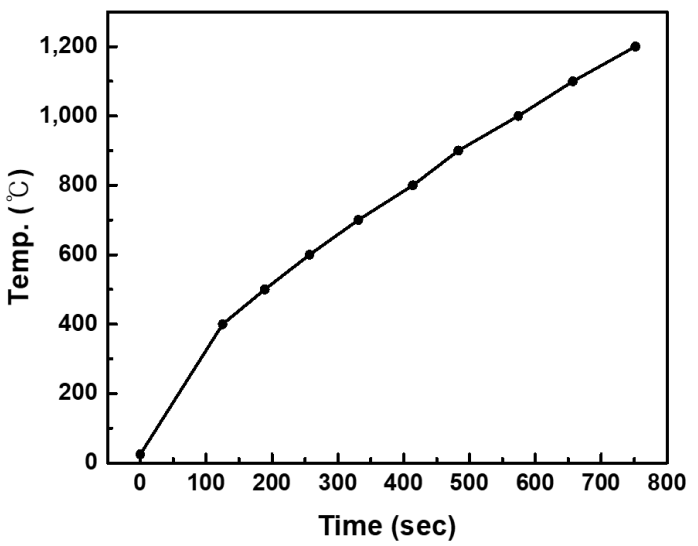

Fig. 4. Temperature change with time during microwave irradiation using $\mathrm{SiC}$ plate.

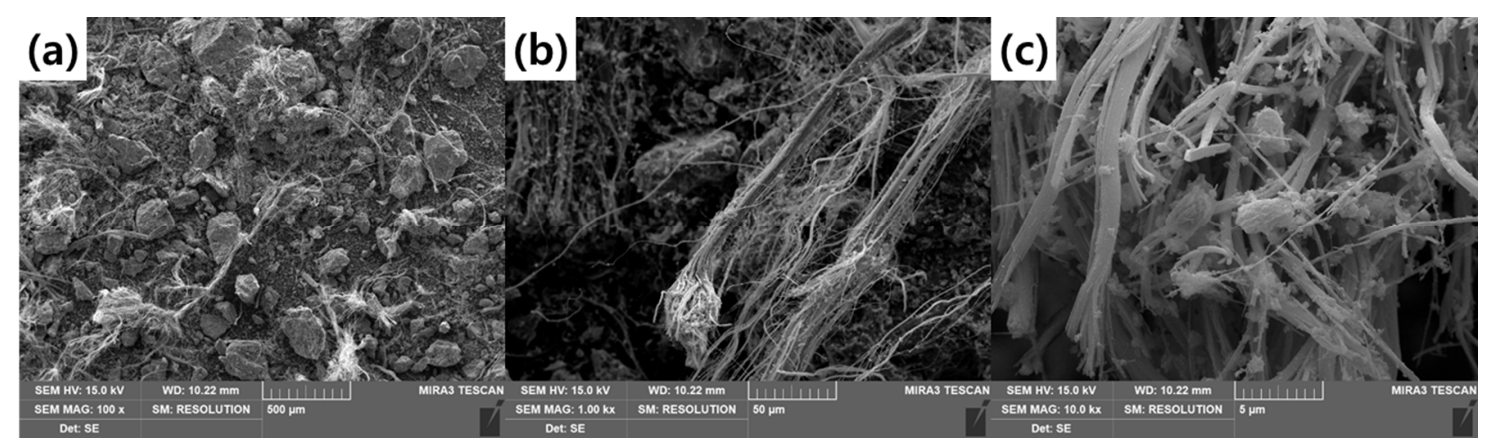

Fig. 3. SEM images of wasted asbestos slate $((a) \times 100,(b) \times 1,000,(c) \times 10,000)$. 


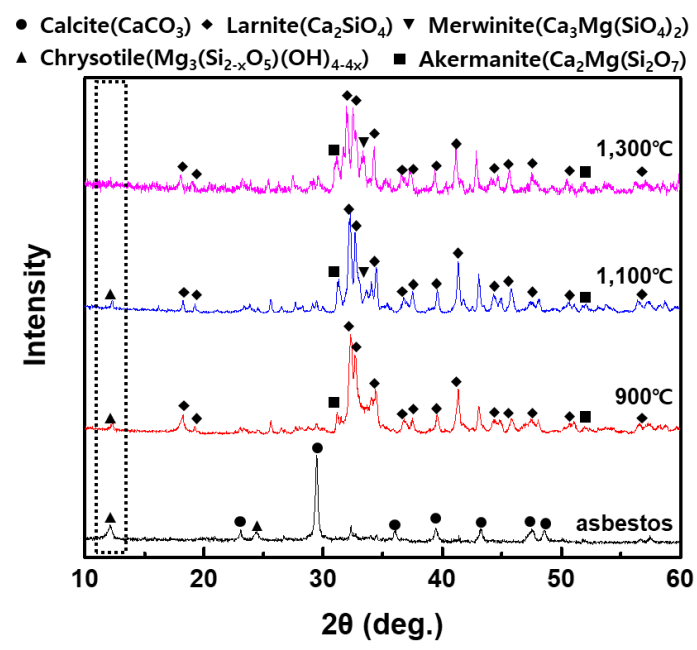

Fig. 5. XRD spectra after heat treatment according to heat treatment temperature.

분해된다 ${ }^{20)}$.

$$
\begin{aligned}
& 2 \mathrm{Mg}_{3} \mathrm{Si}_{2} \mathrm{O}_{5}(\mathrm{OH})_{4} \rightarrow 3 \mathrm{Mg}_{2} \mathrm{SiO}_{4}+\mathrm{SiO}_{2}+4 \mathrm{H}_{2} \mathrm{O} \\
& \mathrm{Mg}_{2} \mathrm{SiO}_{4}+\mathrm{SiO}_{2} \rightarrow 2 \mathrm{MgSiO}_{3}
\end{aligned}
$$

또한 탄산칼슘은 공기 중에서 $900^{\circ} \mathrm{C}$ 에 산화칼슘 $(\mathrm{CaO})$ 과 이산화탄소 $\left(\mathrm{CO}_{2}\right)$ 로 해리되며 생성된 용융점이 $2,572^{\circ} \mathrm{C}$ 인 산화칼슘은 용융점이 $2,572^{\circ} \mathrm{C}$ 인 비정질의 이산화규소
또는 용융점이 $1,557^{\circ} \mathrm{C}$ 인 enstatite, 용융점이 $1,890^{\circ} \mathrm{C}$ 인 forsterite와 용융점 이하에서 다음과 같이 반응하여 larnite (용융점: $2,130^{\circ} \mathrm{C}$ ), merwinite(용융점: $1,487^{\circ} \mathrm{C}$ ), akermanite (용융점: $1,454^{\circ} \mathrm{C}$ )를 형성한다 ${ }^{13)}$.

$$
\begin{aligned}
& 2 \mathrm{CaO}+\mathrm{SiO}_{2} \rightarrow \mathrm{Ca}_{2} \mathrm{SiO}_{4} \\
& \mathrm{MgSiO}_{3}+3 \mathrm{CaO}+\mathrm{SiO}_{2} \rightarrow \mathrm{Ca}_{3} \mathrm{Mg}\left(\mathrm{SiO}_{4}\right)_{2} \\
& \mathrm{MgSiO}_{3}+2 \mathrm{CaO}+\mathrm{SiO}_{2} \rightarrow \mathrm{Ca}_{2} \mathrm{Mg}_{2}\left(\mathrm{Si}_{2} \mathrm{O}_{7}\right)
\end{aligned}
$$

열처리 온도에 따른 폐 슬레이트의 무해화 특성을 파악 하기 위하여 $900^{\circ} \mathrm{C}, 1,100^{\circ} \mathrm{C}, 1,300^{\circ} \mathrm{C}$ 에서 30 분간 열처 리한 폐 슬레이트의 미세구조를 SEM으로 분석한 결과 를 Fig. 6에 나타냈다. 모든 샘플의 저배율 $(\times 100)$ SEM 분석에서는 석면 섬유상을 확인 할 수 없었으나 고배율(× $10,000)$ 에서는 $900^{\circ} \mathrm{C}, 1,100^{\circ} \mathrm{C}$ 열처리 샘플에서는 섬유 상이 확인되었으며 $1,300^{\circ} \mathrm{C}$ 에서는 석면 섬유상이 나타 나지 않았다. $900^{\circ} \mathrm{C}, 1,100^{\circ} \mathrm{C}$ 로 열처리한 샘플에서도 열 처리 전 뵤족하고 날카로웠던 섬유상의 끝부분이 뭉툭하 고 잘린 듯한 형상으로 변한 것을 확인되었는데 이러한 결과는 XRD 분석에서도 나타난 바와 같이 chrysotile이 forsterite와 enstatite로 해리되면서 석면의 섬유상 조직이 변형된 것으로 예상된다. 또한 $1,300^{\circ} \mathrm{C}$ 로 열처리한 샘플 에서는 XRD의 chrysotile이 완전히 없어지면서 섬유상

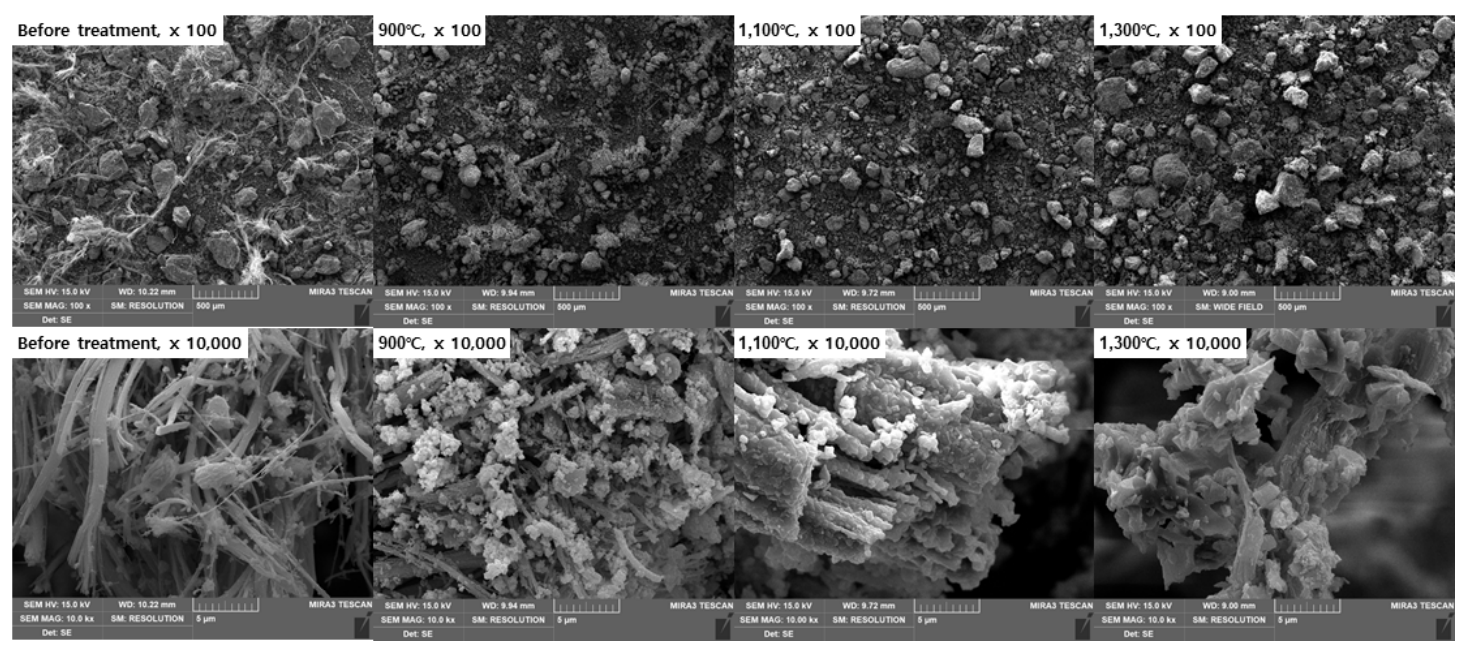

Fig. 6. SEM images after heat treatment according to heat treatment temperature. 

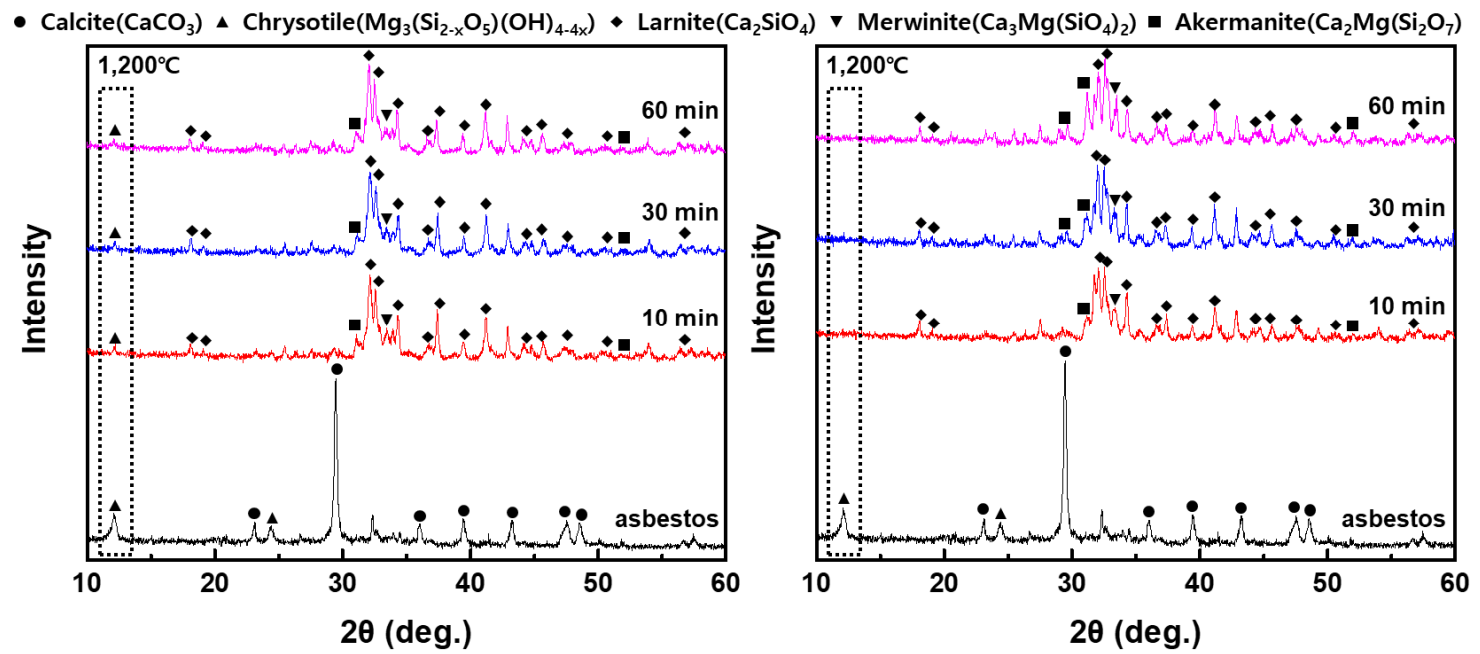

Fig. 7. XRD spectra after heat treatment according to heat treatment temperature and time.

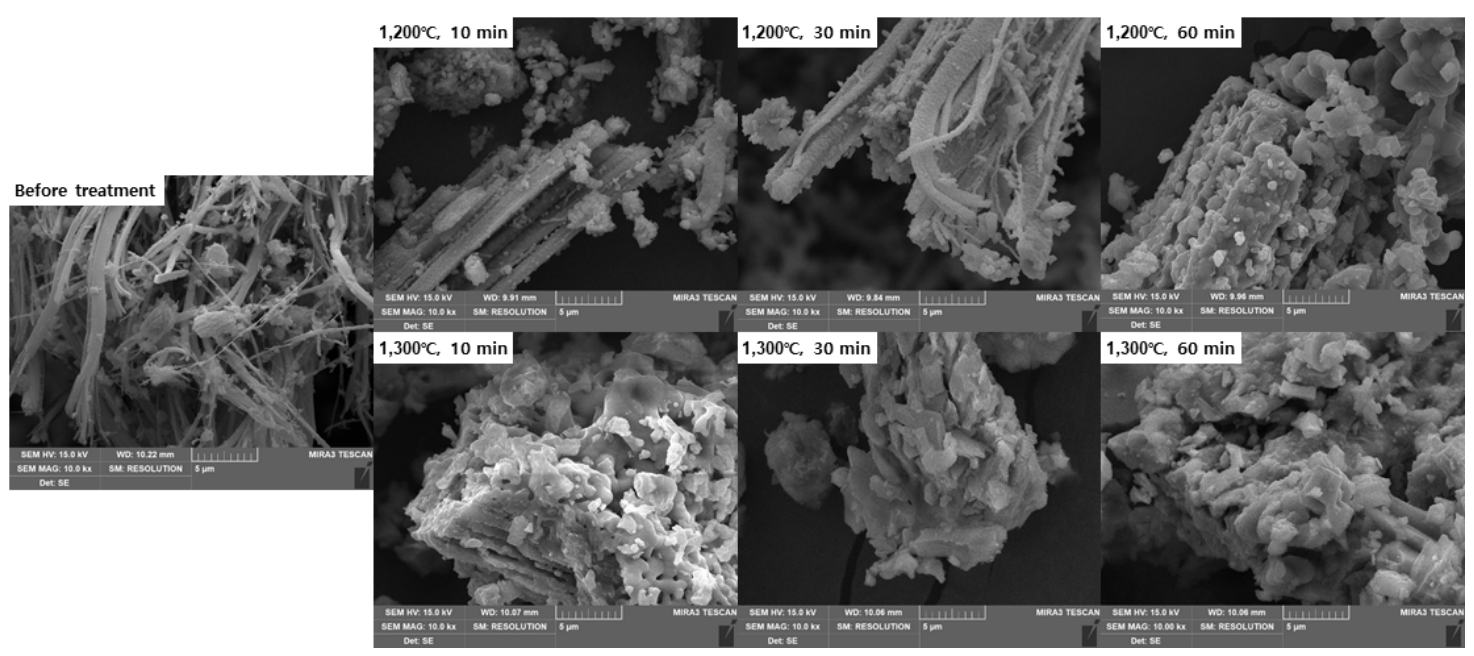

Fig. 8. SEM images after heat treatment according to heat treatment temperature and time.

조직도 함께 변형된 것으로 생각된다.

석면 무해화 공정의 최적 온도와 시간을 확인하기 위해 서 $1200^{\circ} \mathrm{C}, 1300^{\circ} \mathrm{C}$ 에서 10 분, 30 분, 60 분 동안 마이크로 웨이브 열처리 장치를 이용한 열처리 실험을 진행한 폐 슬 레이트의 XRD 분석결과를 Fig. 7에 나타내었으며 SEM 분석결과를 Fig. 8 에 나타내었다. XRD 분석결과, Fig. 7 에서 볼 수 있듯이 $1,200^{\circ} \mathrm{C}$ 의 열처리 온도 조건에서는 모 든 열처리 시간 조건에서 chrysotile 결정상이 약하게 남 아 있는 것을 확인 할 수 있었으며 $1,300^{\circ} \mathrm{C}$ 의 열처리 온도 조건에서는 모든 열처리 시간 조건에서 chrysotile 결정상
이 나타나지 않음을 확인하였다. SEM 분석결과, Fig. 8 에 서 볼 수 있듯이 $1,200^{\circ} \mathrm{C}$ 로 열처리를 한 샘플의 경우, 열 처리 시간 10 분과 30 분에서는 섬유상이 확인 되었으나 60 분에서는 섬유상이 발견되지 않았으며 $1,300^{\circ} \mathrm{C}$ 로 열처리 를 진행하였을 때, 섬유상이 완전히 분해되어 섬유상이 확 인되지 않았다. 온도와 시간에 따른 결정구조 및 미세구 조 분석을 통하여 $\mathrm{SiC}$ 플레이트를 이용 시, $1,300^{\circ} \mathrm{C}, 10$ 분 또는 $1,200^{\circ} \mathrm{C}, 60$ 분이 열처리를 통한 석면의 완전 무해화 를 위한 최적의 조건으로 판단된다. 


\section{4. 결 론}

본 연구에서는 마이크로웨이브 열처리 공정을 사용하 였으며, 발열하는 $\mathrm{SiC}$ 무기 발열체 플레이트 사이에 석면 함유 폐기물 분말을 위치시켜 성공적으로 석면 함유 폐기 물을 무해화 할 수 있었다. 최적의 석면 함유 폐기물에서 의 석면 무해화 조건 도출을 위하여 무해화 열처리 온도 $\left(900 \sim 1,300^{\circ} \mathrm{C}\right)$ 와 시간 $(10 \sim 60 \mathrm{~min})$ 의 조건에 따른 무해 화 결과를 확인하였다. 우선 연구에 사용되는 석면 함유 폐기물 미분분말의 결정성 분석을 통하여 석면 함유 폐기 물 주성분인 chrysotile과 시멘트의 주성분인 탄산칼슘을 확인할 수 있었으며, 석면 함유율이 상대적으로 높고 미분 화 공정 후에도 석면 섬유상을 그대로 가지고 있음을 확인 하였다. 기존 마이크로웨이브를 이용한 열처리 시 상온에 서 낮은 마이크로웨이브 흡수율로 인한 가열이 어려운 한 계점을 상온에서도 마이크로웨이브 흡수가 가능한 $\mathrm{SiC}$ 플 레이트의 적용을 통하여 해결하고자 하였으며 실험 결과 상온에서도 빠른 가열이 가능한 것을 확인하였다. 각 열처 리 조건에 따른 마이크로웨이브 열처리 공정을 진행한 후 의 결정구조 분석을 통하여 폐 슬레이트의 함유된 탄산칼 슘과 chrysotile이 무해화 열처리를 진행한 후 akermanite, merwinite, larnite 결정상이 생성되는 것을 확인하였다. 설정한 열처리 온도와 시간에 따른 무해화 실험 결과, 열 처리 온도 $1,200^{\circ} \mathrm{C}$ 에서는 60 분 이상, $1,300^{\circ} \mathrm{C}$ 에서는 10 분 이상 열처리 공정을 진행하였을 때, chrysotile의 결정 상이 사라지고 SEM 분석 결과에서도 섬유상의 석면 조직 이 완전히 분해된 것을 확인하였다. 본 연구를 통하여 무 기소재인 $\mathrm{SiC}$ 플레이트를 적용한 마이크로웨이브 열처리 방법을 이용하여 석면 함유 폐기물을 무해화 하는데 성공 하였으며, 본 방법을 이용하면 단시간 내에 목표 온도로 가열이 가능하고 에너지 소비량을 줄일 수 있으며, 석면 미분분말과 무기소재의 혼합 단계를 제외함에 따른 공정 의 단순화로 인해 경제적으로 석면을 무해화 하여 재활용 할 수 있을 것으로 기대된다.

\section{감사의 글}

본 연구는 환경부 환경산업선진화기술개발사업의 지 원으로 수행되었으며 이에 감사드립니다(과제번호: 1485 015486).

\section{References}

1. Leonelli, C., Veronesi, P., Boccaccini, D. N., et al., 2006 : Microwave thermal inertisation of asbestos containing waste and its recycling in traditional ceramics, J. Hazard. Mater., 135(1-3), pp.149-155.

2. Skinner, H. C. W., 2003 : Mineralogy of asbestos minerals, Indoor Built Environ., 12(6), pp.385-389.

3. Donaldson, K., Tran, C. L., 2004 : An introduction to the short-term toxicology of respirable industrial fibres, Mutat. Res. Fundam. Mol. Mech. Mutagen., 553(1-2), pp.5-9.

4. Kusiorowski, R., Zaremba, T., Piotrowski, J., et al., 2012 : Thermal decomposition of different types of asbestos, J. Therm. Anal. Calorim., 109(2), pp.693-704.

5. Gualtieri, A. F., Tartaglia, A., 2000 : Thermal decomposition of asbestos and recycling in traditional ceramics, J. Eur. Ceram. Soc., 20(9), pp.1409-1418.

6. Wagner, J. C., Sleggs, C. A., and Marchand, P., 1960 : Diffuse pleural mesothelioma and asbestos exposure in the North Western Cape Province, Occup. Environ. Med., 17(4), pp.260-271.

7. Newhouse, M. L., Thompson, H., 1965 : Mesothelioma of pleura and peritoneum following exposure to asbestos in the London area, Occup. Environ. Med., 22(4), pp.261269.

8. Selikoff, I. J., Hammond, E. C., 1968 : Environmental epidemiology. 3. Community effects of nonoccupational environmental asbestos exposure, Am. J. Public Health Nations Health, 58(9), pp.1658-1666.

9. Turci, F., Colonna, M., Tomatis, M., et al., 2010 : New detoxification processes for asbestos fibers in the environment, J. Toxicol. Environ. Health, Part A, 73(5-6), pp.368377.

10. Werner, A. J., Hochella, M. F., Guthrie, G. D., et al., 1995 : Asbestiform riebeckite (crocidolite) dissolution in the presence of Fe chelators: implications for mineral-induced disease, Am. Mineral., 80(11-12), pp.1093-1103.

11. Block, J., Petrakis, L., Dolhert, L. E., et al., 2000 : A novel approach for the in-situ chemical elimination of chrysotile from asbestos-containing fireproofing materials, Environ. Sci. Technol., 34(11), pp.2293-2298.

12. Gomez, E., Rani, D. A., Cheeseman, C. R., et al., 2009 : Thermal plasma technology for the treatment of wastes: a critical review, J. Hazard. Mater., 161(2-3), pp.614-626.

13. Gualtieri, A. F., Cavenati, C., Zanatto, I., et al., 2008 : The transformation sequence of cement-asbestos slates up to $1200^{\circ} \mathrm{C}$ and safe recycling of the reaction product in stoneware tile mixtures, J. Hazard. Mater., 152(2), pp.563- 
570.

14. Jolicoeur, C., Duchesne, D., 1981 : Infrared and thermogravimetric studies of the thermal degradation of chrysotile asbestos fibers: evidence for matrix effects, Can. J. Chem., 59(10), pp.1521-1526.

15. Kashimura, K., Yamaguchi, T., Sato, M., et al., 2014 : Rapid transformation of asbestos into harmless waste by a microwave rotary furnace: application of microwave heating to rubble processing of the 2011 Tohoku earthquake, J. Hazard. Toxic. Radioact. Waste, 19(3), pp.04014041.

16. Borderes, A., 2000 : Vitrification of the incineration residues,
Verre-Paris Then Versailles-, 6(4), pp.19-21.

17. Jianmiao, D., Shizong, L., 2005 : Effect of microwave processing on aluminate cement clinkering, J. Wuhan Univ. Technol., Mater. Sci. Ed., 20(2), pp.77-79.

18. Clark, D. E., Sutton, W. H., 1996 : Microwave processing of materials, Annu. Rev. Mater. Sci., 26(1), pp.299-331.

19. Kozawa, T., Onda, A., Yanagisawa, K., et al., 2010 : Thermal decomposition of chrysotile-containing wastes in a water vapor atmosphere, J. Ceram. Soc. Jpn., 118(1384), pp. 1199-1201.

\section{홍 명 환}

- 한양대학교 신소재공학과 공학석사

• 현재 고등기술연구원 융합소재연구센터 선임연 구원

\section{이 찬 기}

- 단국대학교 에너지공학과 석사

- 현재 고등기술연구원 융합소재연구센터 연구원

\section{최 혁 목}

- 신라대학교 환경공학과 공학박사

- 현재 (주)한국종합플랜트 플랜트사업부, 이사
- 일본 큐슈대 물질이공학과 공학박사

- 현재 고등기술연구원 융합소재연구센터 수석연 구원

- 당 학회지 제 26 권 4 호 참조

\section{윤 진 호}

- 서울시립대학교 신소재공학과 공학박사

- 현재 고등기술연구원 융합소재연구센터 책임연 구원

- 당 학회지 제 25 권 2 호 참조 